\title{
Hybrid Creatures in Context: Centaurs, Hobby- horses and Sexualised Women (Hamlet, King Lear, The Two Noble Kinsmen)
}

Natália Pikli

\section{(2) OpenEdition \\ 1 Journals}

\section{Electronic version}

URL: http://journals.openedition.org/shakespeare/5055

DOI: $10.4000 /$ shakespeare.5055

ISSN: 2271-6424

Publisher

Société Française Shakespeare

\section{Electronic reference}

Natália Pikli, « Hybrid Creatures in Context: Centaurs, Hobby-horses and Sexualised Women (Hamlet, King Lear, The Two Noble Kinsmen) ", Actes des congrès de la Société française Shakespeare [Online], 38| 2020, Online since 10 January 2020, connection on 21 July 2020. URL : http://

journals.openedition.org/shakespeare/5055; DOI : https://doi.org/10.4000/shakespeare.5055

This text was automatically generated on 21 July 2020.

(C) SFS 


\title{
Hybrid Creatures in Context: Centaurs, Hobby-horses and Sexualised Women (Hamlet, King Lear, The Two Noble Kinsmen)
}

\author{
Natália Pikli
}

"Think when we talk of horses, that you see them", says the Chorus in Henry V, alluding to the fact that Shakespeare's and his contemporaries' works teem with horses the audience had to imagine, since bringing a live horse onto the stage was rarely a viable option. Besides the war horses of historical battles, early modern playtexts featured other horses or horse-like creatures, belonging to different cultural discourses. Besides the "elite" centaur of humanist education, the hobby-horse of the morris dance, the wickerwork costume of the dancing, prancing, lascivious and merry character (Figure 1) enjoyed heightened popularity in the decades between 1580 and 1642 , appearing in numerous texts of different status, ${ }^{2}$ being the most remembered when it was so famously "forgotten" (cf. the resounding phrase in Hamlet "For oh, for oh, the hobby-horse is forgot", 3.2.143-144). The allusions to these half-horse, half-man hybrid creatures frequently intermingled with shrew-taming discourses, which relied on the equation of unruly horses and women, thus creating a rich tapestry of interconnected images and concepts in the early modern imagination. 


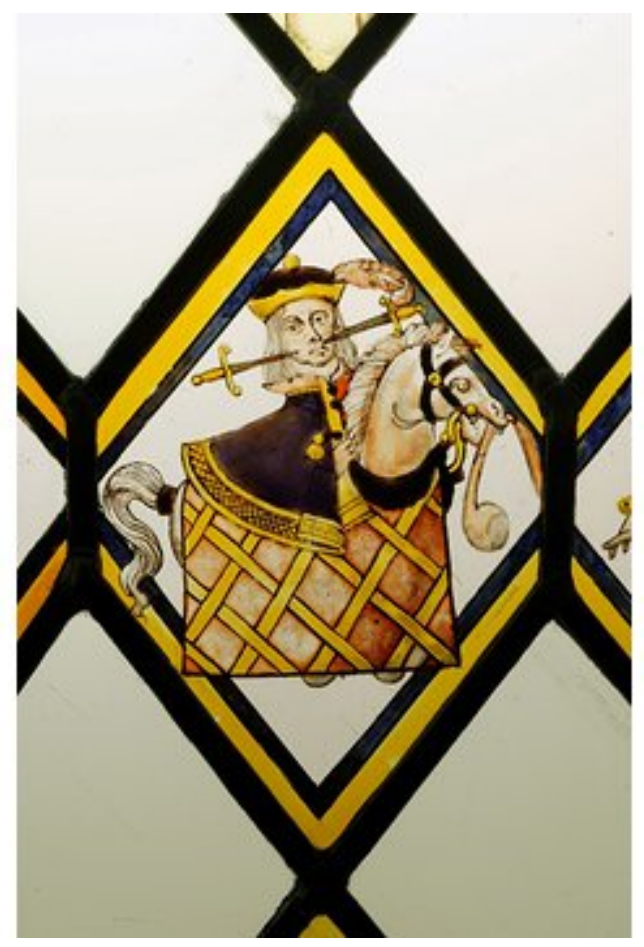

Figure 1. The Betley Window detail, 'Hobby-horse' (1550-1621), Victoria and Albert Museum. London.

IMAGE ID 2013GR6055.

2 The present study investigates the colourful and varied cultural background to centaur-like imagery in Shakespeare, comparing contemporary discourses on centaurs and hobby-horses, highlighting the most important clusters of cultural imagination in several popular texts, emblems, and Edward Topsell's 1607 treatise on beasts. Then it focuses on passages in Hamlet, The Two Noble Kinsmen and King Lear, discussing how the hobby-horse and pertaining gendered popular discourses may have affected the reception and interpretation of such imagery by the contemporary audience. In these Shakespearean passages the elitist centaur mingles with the popular and rural hobbyhorse (which was frequently, though not exclusively, associated with the morris dance), which results in a multi-layered representation of the man-horse hybrid. The study argues that whereas centaurs could symbolize a mastery of horsemanship in a practical sense, and, by extension, a mastery of reason over passion in allegorical terms (a phenomenon also prominent in emblem books), the playful "dancing-prancing" mastery of the hobby-horse could occasionally modify such moral message. On the other hand, the monstrosity and bestiality of the hybrid centaur, and especially that of the female centaur in King Lear appears in interaction with the gendered use of the polysemous word 'hobby-horse', which often referred to 'a whore', that is, illicit female sexuality, as in the famous instances in Love's Labour's Lost, Othello and The Winter's Tale. ${ }^{3}$

3 In a larger philosophical context, the essential hybridity of the centaur and gendered allusions to hobby-horses problematizes the division between human and animal, man and woman. Renaissance thinkers tended to heighten awareness regarding the "porous boundaries" between man and beast, ${ }^{4}$ whereas popular gendered discourses connected unruly women and horses. Wider theoretical repercussions of the centaur imagery have been investigated in inspiring studies, with the passage from King Lear receiving 
heightened scholarly attention in informative studies by Laurie Shannon, Eric Brown, Andreas Höfele, Jonathan Bate and others. ${ }^{5}$ This paper goes a step further and claims that the mingling of elite and popular discourses becomes a significant factor in the interpretation of the horse-rider and centaur-like imagery in Claudius's reference to the "French horseman", and in Arcite's death in The Two Noble Kinsmen. Finally, Lear's famous allusion to his daughters as female centaurs is re-visited in the light of early modern popular discourses regarding the hobby-horse, which connect illicit sexuality to women and unruly horse-like figures.

Ruling a horse was a general symbol, and often an emblem of mastery and control, originating as much in Plato's reference to soul and body in Phaedrus as in everyday experience. ${ }^{6}$ The able rider came to symbolize potent rule, reason's mastery over beastly passion, often with a gender bias: contemporary shrew-taming narratives associated unruly horses with unruly women throughout Europe. As Boehrer summarizes, the opposition of the bestial, sexualised female and the rational male was pictured as the horse and rider throughout the early modern world, with the mare frequently becoming "a powerful emblem of feminine unchastity." We have comprehensive accounts of English shrew-taming discourses, ${ }^{8}$ which prove the ubiquity of such associations in Shakespeare's works.

\section{Man-horse hybrids in early modern England: the hobby-horse and the centaur}

5 The horse was as unalienable part of early modern discourse in Europe as cars are now, as Karen Raber and Treva J. Tucker explain in an illuminating simile in The Culture of the Horse. ${ }^{9}$ Early modern people - as opposed to our days - were in everyday contact with horses and objects which belonged to horsemanship: words like 'hackney', 'courser', 'jade', 'palfrey', 'bridle', 'crupper' were part of everyday discourse, ${ }^{10}$ similarly to how even a child can distinguish a Toyota from a Volvo in our days. Therefore, it is no wonder horses are ubiquitous in Shakespeare's and his contemporaries' works. On the other hand, everyday horses often featured together with unique or mythicalmetaphorical horses in authorial discourse, thus attesting to a varied and colourful semantic field regarding horse-like creatures. George Wither's A Collection of Emblemes (1635) proves illuminating regarding how many kinds of horses were recalled by Shakespeare's quasi-contemporaries.

Wither's work relied on the copperplates of the famous emblem book Nucleus Emblematum Selectissorium (1611-13), which was co-produced by the poet Gabriel Rollenhagen and artist Crispijn van Passe, for the picture and motto part of each page. Wither, however, provided an accompanying 30-line poem, to "quicken", that is, "bring to life" the original pictorial part of the emblem, ${ }^{11}$ and these often tiresome but informative passages witnessed to Wither's Englished moralization and actualization of the original emblem. In the emblem on Pegasus, Wither's poem refers to race horses, Bank's famous performing horse Morocco, hobby-horses, and Bucephalus, Alexander's horse. Although the picture features Pegasus, a core symbol of Humanist-elitist culture (Emb. 'Recto Curso', Figure 2), the verse contextualises the Muses' horse with biting social criticism, reflecting on Englishmen's negligence of both learning and knowledge, and their preference for drinking, gaming, and popular entertainment. 


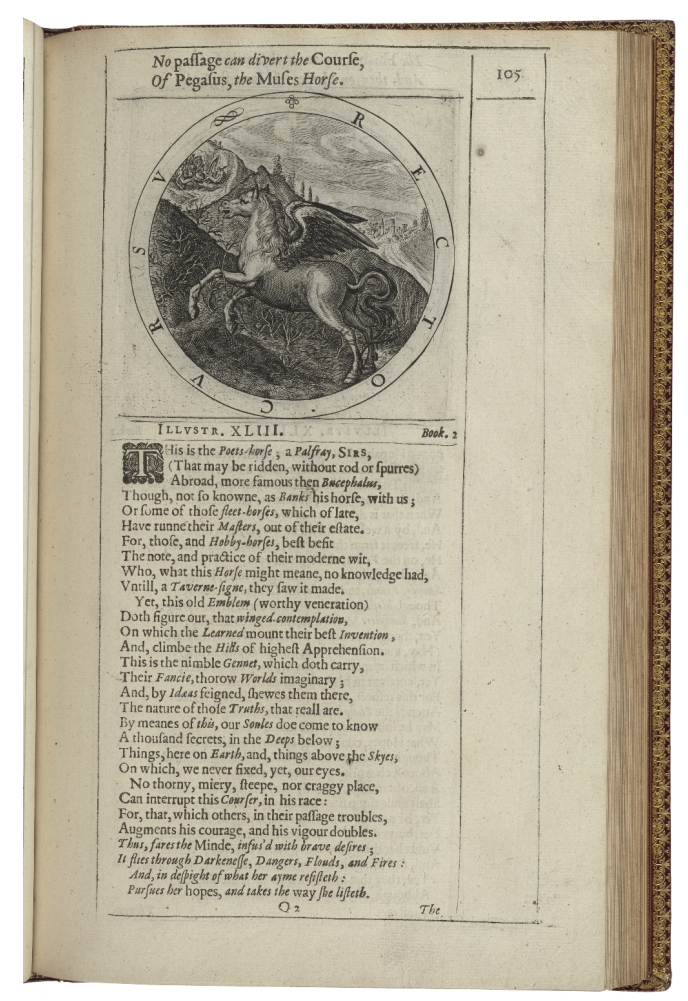

Figure 2. Emblem “Recto curso", George Wither, A Collection of Emblems, Book 2, Leaf Q2r (p. 105).

\section{Folger Luna Digital Image Collection, 112899}

In such a vast semantic field of early modern horses, the two composite equine beings, the centaur and the wickerwork costume of the hobby-horse deserve special attention. They are similar, since both are half-man, half-horse hybrids, however, they originate in disparate traditions. ${ }^{12}$ The dancing and prancing hobby-horse arose from native and popular traditions, it was often (but not exclusively) connected to morris dancing, and became a "popular emblem" (in Laroque's useful phrase), signifying popular culture at large. ${ }^{13}$ The most well-known and detailed description of the rural morris dance with hobby-horses during May Day festivals is provided by the puritan Philip Stubbes. Despite his obvious bias, the account corresponds to other historical and documentary evidence we have of morris dances with the hobby-horse:

Thus al things set in order, then have they their Hobby-horses, dragons \& other Antiques, togither with their baudie Pipers and thundering Drummers to strike up the deuils daunce withal, then marche these heathen company towards the Churchyard, their pipers pipeing, their drummers thundring, their stumps dauncing, their bels iyngling, their handkerchefs swinging about their heds like madmen, their hobbie horses and other monsters skirmishing amongst the route: ${ }^{14}$

We have two contemporary pictorial representations of the morris hobby-horse, the so-called Betley Window (Figure 1) and Vinckenboom's painting The Thames at Richmond, with the Old Royal Palace. ${ }^{15}$ Although they may only be accepted with a pinch of salt regarding authentic representation, due to their synthesising genre requirements, and with the Betley Window synthetising features of different rural festivities from maypole to sword dance), they do attest to the popularity and composite being of the early modern hobby-horse. The stain-glass window in Betley Hall, depicting the month of May, is most probably a mid-sixteenth-century depiction of traditional May Day 
characters, ${ }^{16}$ mostly modelled on Israhel van Meckenem's picture in the late $15^{\text {th }}$ century Strasbourg Almanac. ${ }^{17}$ Significantly, the maypole and the hobby-horse (and some smaller details) are 'Englished' additions to Meckenem's characters, and are without a former continental model. ${ }^{18}$ The Window shows this half-man, half-horse hybrid in its full glory, among other festive characters of rural May Games.

Vinckenboom's picture is a landscape painting, and although it seems to give an authentic depiction of a morris dance complete with a hobby-horse, some degree of idealization, arising from genre expectations, cannot be excluded. The morris hobbyhorse in this landscape appears among the morris dancers, without the ladle, since it is now the Fool who interacts with the middle-class and aristocratic onlookers. Nevertheless, these depictions show clearly how this wickerwork costume of the dancing, prancing, flirtatious hobby-horse lived in Shakespeare's contemporaries' imagination.

On the other hand, as mentioned, one of the most frequent meanings of the word 'hobby-horse' referred to 'loose' women, as can be seen in the well-known Shakespearean examples in Love's Labour's Lost, Othello and The Winter's Tale. This gender-switch was partly occasioned by the close association of the morris hobby-horse and unruly women, who often danced and played together during morris dances, in a form of sexual flirtation, to celebrate joyful fertility on such carnivalesque occasions like May Day. This is evident in Cobbes' verses: "But when the Hobby-horse did wihy, / oh pretty wihy, / Then all the Wenches gaue a tihy, /oh pretty tihy." ${ }^{19}$ On the other hand, this gender-switch originated in the easy associative leap between unruly women and unruly horses to be tamed and ruled by male reason and power, which was dominant in shrew-taming discourses.

11 The centaur, on the other hand, is a fully imaginary, and predominantly male being, the word coming to English from Latin and/or French, taking its origins in Greek mythology and Pliny. ${ }^{20}$ Therefore, the centaur is strongly connected to elite culture in the early modern imagination, occupying a prominent position in emblem books. It appears in the title page of a Dutch emblem book from 1614 named after Bellerophon, the legendary first rider (Dierck Pietersz' Bellerophon, of Lust Tot Wyshed) ${ }_{,}^{21}$ and a centaur features in Rollenhagen's emblem book (Emb. 91, 'Viribus iungenda Sapientia'), which is re-used and dilated on by Whiter (Figure 3) in Book 2, Illustr. XLI, without altering the original reference to the conflict of soul and body. Wither highlights how "this halfe-a man, and half-a horse [...] ancient Hieroglyphicke" teaches the reader/spectator that "Wisdome should be joyne'd with ouward force, / If prosperous, we desire our works to be", and finally prays to God to help him in achieving this. He clearly explains what refers to what: "His Upper-part, the shape of Man, doth beare, / To teach, that, Reason must become our guide [...] The hinder-parts, a Horses Members are; / To shew, that we must, also, strength provide". This interpretation proved the most widespread in Shakespeare's age. However, as we will see later, Ovid's Metamorphoses and other popular works in natural history like Edward Topsell's, often modified and completed such simplified explanations like the one by Wither. 


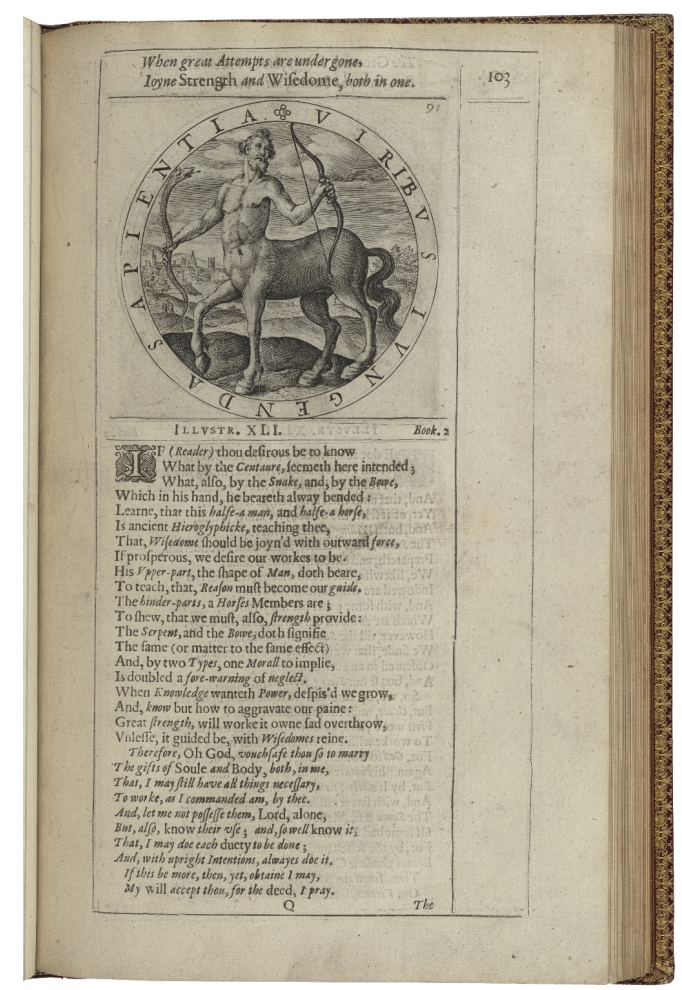

Figure 3. Emblem "Viribus iungenda Sapientia", George Wither, A Collection of Emblems, Book 2, Leaf Q1r(p. 103).

\section{Folger Luna Digital Image Collection, 112897.}

The medieval heritage proved quite ambiguous, though predominantly centaurs were connected to negative imagery. ${ }^{22}$ They often were opposed to the 'noble knight' (both 'riders'), signifying the vice of Pride and Ambition. In late medieval-early Renaissance iconography, centaurs often appeared in marginal decoration of illuminated codices, and signified the beastly, earthly part of beings. ${ }^{23}$ The hybrid nature of the centaur led Physiologus to the idea that the centaur corresponds to the heretic, who is aware of the teachings of Christianity but is unable to employ them in appropriate ways, therefore his nature remains dual. On the other hand, since Chiron was the wise tutor of Achilles, a beneficient connection to nature and the natural also contributed to the complex imagery of the centaur, together with the idea of wisdom. Based on such disparate trends of tradition, the centaur entered the Renaissance as a highly ambiguous sign. Besides the allusion to the Ovidian duplex natura of the elite centaur, ${ }^{24}$ these diverging attributions led to both stigmatisation and adoration of the centaur, ranging from becoming a role model in a Prince's education by Machiavelli to demonization in King Lear.

\section{Masterful riders and Claudius's "French horseman" in Hamlet}

13 As pointed out by Brown in his inspiring and comprehensive article on centaurs in Shakespeare, according to Pliny's Natural History (translated by Philemon Holland in 1601), the horsemen of Thessaly were first seen as centaurs, they looked as if they were 
"rooted in the saddle": "Bellerophon shewed first how to ride on horseback [...] the Thessalians, called Centaures, inhabiting neere to the mountain Pelius, were the first that fought on horsebacke." ${ }^{25}$ The same idea occurred already in the "father of all emblem books", in Alciato's Emblematum Liber, 1531, and in 1565 in England in Thomas Cooper's Thesaurus ("Hippocentauri, Were a people in Thessalia by the mounte of Pelius, which were also called Centauri, the which were the first that were seen in Greece ryding upon horses"). ${ }^{26}$

Interestingly, Edward Topsell's famous and comprehensive natural history echoes the same idea in the chapter "Of Riding" in The History of foure-footed beastes, published in 1607 , as the first part of his adapted translation of Konrad Gesner's comprehensive zoologia, Historia Animalium. ${ }^{27}$ Topsell's huge enterprise deserves closer attention, since it is a compendium of the age's concepts on animals, collecting not only scientific and objective data but completing these with "Narrations out of Scriptures, Fathers, Phylosophers, Physitians, and Poets", as well as with "Hyerogliphics, Emblems, Epigrams, and other good Histories", according to the title page. Naturally, such a varied compendium of sources proves difficult to handle, and when Topsell talks about the invention of the art of riding, he keeps a cautious middle field regarding rival discourses, saying that

The Meades, Persians, and Armenians, were the first that invented the art of riding and shooting, (as Strabo saith,) Pausanias cald Neptune Hippeos for no other cause, but that it was supposed he was the first invented the art of riding. Pollidorus ascribeth it to Bellerophon, Lysisas the Orator saieth that the Amazonia Women were the first of all mortall creatures that first adventured to backe Horses. Others ascribe it to the Centaures: But to leauve the invention, and come to the Art. ${ }^{28}$

Illustrative examples for the centaur as the masterful rider are also to be found in Thomas Nicholas' translation of F. Lopez de Gómara's Pleasant History of the Conquest of West India (1578), where he refers to the masterful rider as a centaur: "Thinking that he hadde bin a Centaure and that the Horse and man was all one incorporate" (emphasis mine), ${ }^{29}$ which is echoed in the Hamletian passage on the French horseman. ${ }^{30}$ The mastery of rider above horse is expressed by the imaginative fusing the two bodies, however, the rider's place on the horse's back differs from the positioning of the upper human part of the centaur, and rather recalls that other famous horse and rider image of the age, the hobby-horse.

The morris hobby-horse also signified a mastery in horsemanship - even if with a tongue in cheek. It was praised as prancing, dancing, as if man were one with the horse, flirting with the audience or attacking them in a humorous way, as can be seen in, for instance, Thomas Nashe's A Pleasant Comedie, called Summers last will and Testament. The hobby-horse's dance is praised by Will Summer, although he also warns that: "You friend with the Hobby-horse, goe not too fast, for feare of wearing out my Lords tylestones with your hob-nayles." ${ }^{31}$ Ver soon dismisses the hobby-horse, with the words "So, so, so, trot the ring twice over and away" (ibid.), but its appearance attests to a masterful handling of the 'horse' by the 'rider', entertaining both on-stage and offstage audiences.

17 In such a light Claudius's "French horseman" passage in Hamlet is worth re-visiting, since this textual crux is traditionally explained in scholarship as a straightforward centaur reference. The passage is missing from the 1603 First Quarto but is present with only a minor variation in the Second Quarto and the First Folio ${ }^{32}$ : 


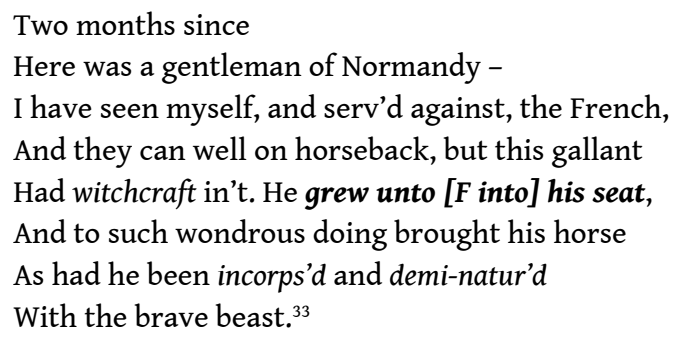

The latest Arden edition confirms that "the King is imagining the Norman and his horse as being the mythical Centaur, half-man, and half-horse". ${ }^{34}$ Earlier, Harold Jenkins offered a brief though sophisticated explanation in his glossary and "Longer Notes", where he also referred to Sidney's Arcadia, and explained "incorps'd" as the following: "as if Centaur-like he had been one piece with the horse [...] the centaur-like description of the Norman, whose identity merges with that of the beast, seems to make him an emblematic figure. One can hardly help being reminded of the comparison of Claudius to a satyr and of kindred animal images." ${ }^{35}$ However, Jenkins does not mention the possible association with the hobby-horse and popular culture.

Nevertheless, besides the centaur, the positioning of the masterful rider may evoke the morris hobby-horse in the contemporary audience's mind. Although "incorps'd" and "demi-natured" could refer to both man-horse hybrids of centaur and hobby-horse, I argue that the mention of "witchcraft", which is traditionally connected to popular culture and not to elite centaurs, reaffirms such an association in the contemporary audience. In addition, the phrases "grew into/unto his seat" visually recall the hobbyhorse (see Figure 1), not the centaur (Pliny and Thessalian horsemen aside), whose body shows a fusion of the front parts of man and animal, not the rider fused into the seat. Therefore, attributing this allusion to centaurs must be complemented with a potential reference to hobby-horses. The image of the popular hobby-horse is superimposed on the elite centaur, especially in the imagination of the less-educated spectators, the groundlings. Shakespeare was careful to cater for the needs of all segments of his audience, therefore, a possible palimpsest of popular and elite associations seems quite plausible.

\section{Riders in emblems and Arcite's equine death}

Arcite's death in The Two Noble Kinsmen is worth revisiting in the light of such a palimpsest of allusions, since his fate is strongly connected to the widespread image and emblem of the masterful rider, signifying the rule of reason over beastly passion. From Alciato's paradigm-setting emblem book Emblematum Liber, the horse and rider became a well-known emblem of human, male and rational control, becoming a "core" emblem in Moseley's definition. ${ }^{36}$ In Emblem 35 'In adulari nescientem' [On one who knows not to flatter], he confirms that the people of his homeland are noble and never flatter, "like a noble stallion, it throws from its back every horseman who does not know how to control it", going back to Plato's reference in Politicus to the ruler who is an able supervisor of a stud of horses. ${ }^{37}$ Alciato's emblem appeared in many versions in the $16^{\text {th }}$ century, the picture most often depicting a rearing horse controlled by an able rider. The 1584 Paris edition of Alciato served as a model for the same emblem in Geoffrey Whitney's A Choice of Emblemes. ${ }^{38}$ The first stanza of Whitney's poem corresponds to the 'core' meaning of the emblem: 
The tramping steede, that champes the burnish'd bitte,

Is mannag'd braue, with ryders for the nones;

But, when the foole upon his backe doth sette,

He throwes him downe, and ofte doth bruse his bones:

His corage feirce, dothe craue a better guide,

And eke such horse, the foole shoulde not bestride.

Whitney, however, "Englished" the emblem according to his authorial agenda in the second part of the poem, dedicating the emblem to Sir Philip Sidney. ${ }^{39}$ He added a longer moral and generalising message, praising "men of iudgement graue, / of learning, witte, and eeke of conscience cleare", ruling thus in fame. The beautiful and strong horse throws off the fool who cannot control it, but on the other hand, it can be managed by "better guides", good rulers and leaders.

The rearing horse and the unable ('intemperate') rider recalls another, gendered strand of emblematic tradition; the horse's bridle is often connected to Temperance, depicted as a woman. Peacham's Minerva Britanna (1612) offers a very characteristically English treatment of the concept. A beautifully dressed young woman holding a bridle features as Temperance, one of the heavenly virtues (Emblem 93, 'Temperantia', Figure 4). ${ }^{40}$ She, however, is highly sexualised in Peacham's visual presentation: although fully dressed, her breasts and nipples are visible, and her gesture of open arms holding a bridle and a cup respectively suggests invitation rather than control of lust. The verse reads quite morally though:

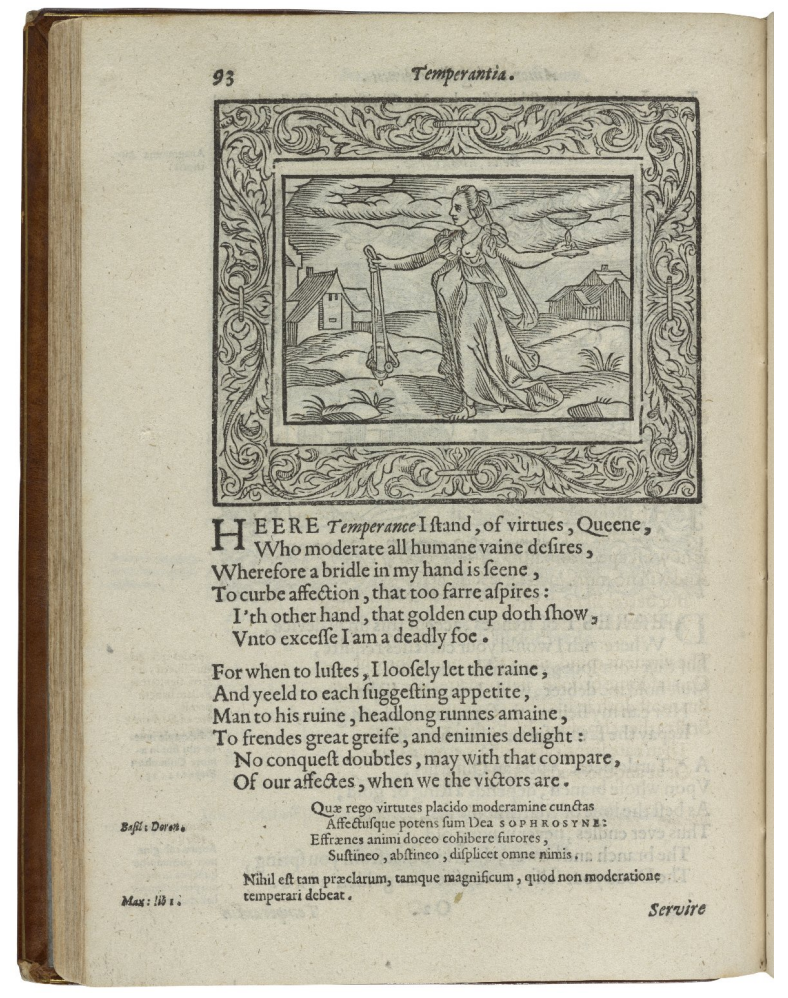

Figure 4. Emblem “Temperantia”, Henry Peacham, Minerva Britanna, p. 93.

FOLgER LUNA COLLECTION, 066944.

In the verse part of the emblem Peacham insists on moral serenity, even quoting a corresponding passage from James I's Basilicon Doron in Latin. However, the visual part of the emblem seems to contradict the serenity of the words, and the reader/gazer 
must decide on the actual lesson drawn from the emblem. On the other hand, this emblem may serve as an interpretative context to the representation of intemperate female sexuality in Lear's reference to his daughters (see later) as well as to intemperance causing Arcite's death in The Two Noble Kinsmen, written not long after the publication of Peacham's emblem book. Although being an excellent rider, Arcite becomes associated with unruliness that finally proves lethal, since throughout the play he attests to a lack of temperance.

Arcite is the one of the two 'sworn brothers', close friends, who are both high-born and noble young men, falling in love with Emilia while in captivity. In opposition to Palamon, however, Arcite's self-identification relies heavily on his horsemanship from the beginning. He introduces himself (in disguise) to Theseus and his royal train as a man of "noble qualities", good at hunting and especially excelling as a rider: "I dare not praise / My feat in horsemanship, yet they that knew me / Would say it was my best piece" (2.5.12-14), and only then adds that he is a soldier as well. No wonder that Pirithous will almost instantly ask him to ride "a rough one" (an untamed horse), which task is happily accepted by Arcite, who rather appears as a bragging soldier or horseman in reply: "I like him better, Prince; I shall not then / Freeze in my saddle" (2.5.47-48). Such stubborn overconfidence may result in recklessness, and will eventually contribute to the death of Arcite, who would not let go of his rearing horse even when his feet were "higher than his head" (5.4.78), as reported by the same Pirithous.

After the decisive tilt between the rivals, Mars's follower, Arcite wears the garland and is on his way to claim the prize, Emilia's hand in marriage, while Palamon, Venus's vassal, waits for his execution. However, the triumphal entry turns into disaster as the proud horse kills its rider unexpectedly. The whole episode is narrated powerfully by Pirithous, and together with Emilia we see Arcite and his horse in our mind's eye. Shakespeare-Fletcher's deviation from their sources proves significant in an emblematic context: while in Boccaccio's Teseida and Chaucer's The Knight's Tale the classical Fury, incited by Saturn, is sent to make "Arcite's horse go wild for no apparent reason", ${ }^{41}$ the play remains more elusive regarding causes. Saturn and his malice only appear in a simile, and the real cause appears to be the "hotness" of the (ominously) black horse, the gift from Emilia: its proud and beautiful trot along the pavement creates the spark that scares it, and turns a magnificent proud steed into an easily frightened, foolish child (taking "toy") and a lowly beast ("pig-like he whines") that finally overcomes its human master. Pirithious's long narration (5.4. 48-82) reinforces the 'incorpsed' hybrid image of Arcite and his horse ("disroot his rider whence he grew", "He kept him between his legs"), which is closer to the appearance of a hobbyhorse than a centaur. The description of the rearing horse and his falling master recalls the emblematic context, the "boist'rous and rough jad'ry" of the horse overcoming the Phaeton-like human rider, who is crushed beneath the weight of a passion he cannot control. Even if he is a master horseman, almost "grown" to the saddle, he can be "disrooted" by unruly passion. ${ }^{42}$

Arcite, the formerly masterful rider, however, is finally subdued by his horse, crushed to death by the animal body. Chaucer has him fall forward from his stumbling horse, but Shakespeare and Fletcher's play presents a more complex metaphor: this image of both falling off and then being pinned down by the horse combines numerous aspects of Arcite's story. His human reason could not control the fiery horse disregarding the 
skilled horsemanship he had boasted of earlier. Arcite contributed to his own death through his stubborn "hot" passion in the courtship for Emilia, and he had an unshaken trust in his horsemanship till the very end. Hot and proud horses cannot be ruled by hot and proud masters, defying Theseus's royal and manly self-restraint, expressed in his dialogue with the mourning queens:

3 QUEEN. [...] for

Thou, being but mortal, mak'st affections bend

To godlike honours; they themselves, some say,

Groan under such mast'ry.

THESEUS. As we are men,

Thus should we do; being sensually subdued,

We lose our human title. (1.1.229-233)

The royal Duke exemplifies the rule of human reason and intellect over sensual passion, appearing similarly to the noble masterful rider of Whitney's emblem and in contrast to Arcite's hot-headed and intemperate passion, which leads to his downfall. "Ut pictura poesis": the cultural given of the able rider as an emblem of control appears in contemporary visual and verbal forms which mutually re-affirm the same message.

\section{Monstrosity: Topsell and the female centaurs in King Lear} rider is also associated with the centaur's duplex natura, in line with the Aristotelian rational and non-rational divide, frequently questioned in this age. ${ }^{43}$ The hybrid nature of the centaur is immanent in its being a man-beast composite, and, as Stewart claims, like all other man-beast composites of Greek mythology (Pan, Proteus, Silenus, satyrs, etc.), "centaurs are notable for extreme wildness and extreme self-indulgence," ${ }^{44}$ signified by the beastly part, as well as wisdom and supernatural powers. Interpreted in bono, in the figure of Chiron, they are the tutors of young heroes from Achilles to Heracles, substitute fathers, who can teach their young protégés the wisdom of excess, that is, how to learn about and then tame the wildest passions. ${ }^{45}$ Interpreted in malo, they signify the bloody actions of ravaging beasts, death, rape and destruction, Nessus' shirt killing the greatest of heroes, Heracles. ${ }^{46}$

Emblems of rarities (1636), when he writes about "The rule and dominion of Prester Ihon":

"It is said also, that there be certaine Monsters, which above the loynes are seene formed like unto men, and beneath the loynes unto horses" (emphasis mine). ${ }^{47}$ Thomas Dekker's 1606 pamphlet, Seven Deadly Sinnes of London also demonizes (even if mathematically incorrectly) centaurs "that are halfe man, halfe beast, and halfe diuell." ${ }^{48}$ Such stigmatisation originates partly in the myths as recounted by Ovid, ${ }^{49}$ partly the medieval-early Renaissance iconographic tradition of centaurs, as signifying the beastly, earthly part of beings.

Topsell also emphasizes the bestiality and monstrosity of centaurs in retelling the stories connected to them. In the first published volume of his translation of Gesner's magisterial work, he focuses on "four-footed beasts", which may be accounted for the fact that in Shakespeare's contemporaries' imagination, the largest and most visible corpus of animals were quadrupeds, which were called "beasts". As Shannon 
emphasizes, the word 'beast' occurs in Shakespeare 141 times as opposed to 'animal', which features only eight times. ${ }^{50}$

Topsell's longest mention of centaurs occurs in the section on "monster horses", where centaurs are first aligned with other portents preceding Julius Ceasar's death. He then talks about "Centaurs [...] described by the Poets to have their foreparts like men, and their hinder parts like horsses", elaborating on the origin story of the Hippocentauri, which is a slightly modified version by Pindarus of the Ovidian myth: "Centaurus the Sonne of Ixion, committed buggery with the mares of Magnetia, under the mountain Pelius, from whence came that monstrous birth in the upper part resembling the father and in the neather the mother", later tamed by Hercules. He defends himself against the accusation of fabrication by saying that "But yet that no man may wonder or think it impossible that such monstrous creatures should have existence in nature, these authorities following may persuade sufficiently", referring to stories of monstrous births by Plutarch, Thales, etc. In recounting the story of the well-known conflict between the Lapiths and the drunken, ravishing, bestial Centaurs at the wedding banquet of Pirithous (most well-known from the retelling of Nestor in Ovid), Topsell moralizes the message in the following way: "whereby the poets signifie how intemperancy in men \& beasts doth not only bring with it other sins, but also causes much slaughter". Finally, he attempts to draw a conclusion, based on such different traditions, and confirms that such unnatural births, producing a horse-man hybrid may be the result of "uncleane and unnaturall copulation", but will never live long, and the centaurs must have been men sitting on horseback "mistaken for one entire creature which were divided". ${ }^{51}$

He finishes with a misquoted line from Horace's Ars poetica, "Humano capiti cernicem [properly: cervicem] Pictor Equinan [equinam]", that is, "To a human head the painter a horse's head [would like to put]", and completes the elliptical Horatian line with his own Latin tag: "Hoc monstrum puto Centaurus foret", that is, "This monster, I think, would be a centaur". ${ }^{52}$ In conclusion, Topsell's emphasis on the monstrous sexuality surrounding the centaurs provides an illuminating contemporary context to Lear's exclamation on unnatural copulation and female centaurs, since Topsell himself seems to revel in the forms of illicit sexuality that surround centaurs from "buggery" to raping, drunken Centaurs of the Lapiths' banquet. Consequently, based on the concepts highlighted by Topsell's book, Lear's unorthodox reference to female centaurs does not seem such a sudden leap from the traditionally male-centered centaur mythology, since intemperance and illicit sexuality provides an easy link between the two:

Down from the waist they are centaurs,

though women all above. But to the girdle do the

gods inherit; beneath is all the fiend's. There's hell,

there's darkness, there is the sulphurous pit; burning,

scalding, stench, consumption! Fie, fie, fie, pah,

pah! (King Lear, Folger Digital Texts, 4.6.130-145)

I argue that this passage fuses two approaches, anthropomorphism and what Boehrer calls "relative anthropocentrism", that is, the bestialised stigmatisation of certain social groups, here women. ${ }^{53}$ Therefore, besides the monstrosity of the centaur, the hobby-horse's hybrid nature and its association with the lustful, unbridled sexuality of women are also evoked in the mad king's words. ${ }^{54}$ that at this "nadir of Lear's misogyny", the patristic idea of equating the women's body 
with "the devil's gateway" is coupled with the male-centaur-like violence of Regan and Goneril. ${ }^{55}$ Höfele, also referring to Topsell's story of Centaurus, adds more meaningfully that "Lear's ultimate image of female monstrosity" creates the centaur in this passage, which is a "monstrous birth of patriarchal myth-making", concluding that such a malefemale transvestite image, this "spectre of monstrous hybridity only serves to lock father and daughters once again in an indissoluble internecine embrace." ${ }^{56}$

I agree with Höfele concerning the duality of gender in this hybrid creature; however, other contexts can be mentioned to complement his argument. The man-woman hybrid was also frequently considered monstrous, not only in the later pamphlet war of Haecvir and Hic-Mulier in the 1620s, but also by the cross-dressed Viola in Twelfth Night, who calls herself a "poor monster" in her monologue, when she realizes how impossible love is in the gender confusion that her disguise created:

How will this fadge? My master loves her dearly,

And I, poor monster, fond as much on him,

And she, mistaken, seems to dote on me.

What will become of this? As I am man,

My state is desperate for my master's love.

As I am woman (now, alas the day!),

What thriftless sighs shall poor Olivia breathe! ${ }^{57}$

Although Lear's daughters never cross-dress, they do become 'manly' in their ruthlessness, and 'monstrous' in exchanging female kindness for manly cruelty. Their trespassing of traditional gender norms instigates a cluster of stigmatising discourses: if they behave like men, they are monsters, and since they are breaking norms, they are unruly both morally and sexually. Illicit sexuality was a stigma often associated with unruly female behaviour from shrews and scolds to witches, therefore it often included a degree of demonization as well. ${ }^{58}$ No wonder that Lear's imagination creates this intriguing compound of female, demonized centaurs: since Goneril and Regan are intemperate in their wickedness, their trespass becomes a cluster of trespasses in terms of man-woman, human-animal, normal-demonic. We have a similarly intriguing gender-switch in the case of the hobby-horse, who was -without exception - played by a man, as we could see in the pictorial representations by the Betley Window and Vinckenboom, and other textual sources, ${ }^{59}$ however, in the semantic shift from the man-played man-horse hybrid of the morris dance to the 'whore' in contemporary slang, a similar demonizing, stigmatizing process can be detected. Lear's mad exclamation combines several co-existing discourses related to centaurs and hobbyhorses. Unruly women, 'loose' in behaviour and, by extension, their sexuality, are stigmatised as whores, 'hobby-horses'. This native tradition of a sexually active manhorse hybrid, often a symbol of fertility in country pastimes, fuses with the centaurs of medieval heritage and those of Humanist learning, interpreted in malo, as dangerously bestial or sexually perverted. It is not only Nature, bestial passion, that rebels here, but significantly, a female appetite, demonized, stigmatised and rebelling against male rule and reason. In one word, women are whores, hobby-horses, female horses and centaurs, who dishonour male family members.

In conclusion, the investigation of the rich and varied cultural imagination related to the man-horse hybrids of centaurs and hobby-horses in early modern England offers an intriguing interpretative background to well-known shakespearean textual loci. Different forms of the horse-rider compound featured in numerous contexts from natural history books to plays and emblems, mingling popular and elite cultural 
discourses on female sexuality. Such a combination of popular and elite phenomena was a forte of Shakespeare's theatrical art. As an "amphibious" author, he was not only well-versed in both the "little" and "great" traditions, but harnessed different discourses that circulated in his age to suit his dramaturgical needs. Although we can never be sure how much of the rich tapestry of the semantical and iconographical associative fields related to centaurs and hobby-horses was evoked in the imagination of Shakespeare's audience by such passages, discovering the rich cultural background of such imagery enables us to see the wide range of potential contemporary reception and interpretation. This, in turn, contributes to our more profound understanding of Shakespearean imagery and allusions.

\section{NOTES}

1. William Shakespeare, Henry V. FTLN0027. All Shakespearean references (except when indicated otherwise) appear according to the Folger Digital Texts, eds Barbara A. Mowat and Paul Werstine. http://folgerdigitaltexts.org. Last accessed 29 April 2019.

2. Precise numbers are difficult to ascertain, since new hits come up the more texts one reads, but, according to Literature Online database search, the word 'hobby-horse' appeared in 9 poems, 35 plays, 4 prose texts between 1580 and 1640. An Early English Books Online search in August 2019 produced 170 hits in 96 records.

3. “ARMADO. But O - But O -

MOTH. 'The hobby-horse is forgot'

ARMADO. Call'st thou my love a 'hobby-horse'?

MOTH. No, master. The hobby-horse is but a colt, and your love perhaps a hackney." (Love's Labour's Lost, 3.1.26-30)

"BIANCA. This is some minx's token, and I must take out the work; there, give it the hobby-horse, wheresoever you had it, I'll take out no work on't." (Othello, 4.1.151-153)

"LEONTES. My wife's a hobby-horse; deserves a name

As rank as any flax-wench that puts to

Before her troth-plight." (The Winter's Tale, 1.2.276-277)

4. Frances Gage, "Human and animal in the Renaissance eye", Renaissance Studies, 31.2 (2017), 261-276, p.264, 268.

5. See Laurie Shannon, "Poor, Bare, Forked: Animal Sovereignty, Human Negative Exceptionalism, and the Natural History of 'King Lear"', Shakespeare Quarterly, 60.2 (2009), 168-196. On Brown and Höfele, see later, in detail.

6. For Plato's simile of the soul as a composite image of "a pair of two winged horses and a charioteer" in Phaedrus (BC 360), see Benjamin Jowett's translation at the Internet Classics Archive (http://classics.mit.edu/Plato/phaedrus.html, last accessed 15 September 2019).

7. Bruce Boehrer, Shakespeare Among the Animals. Nature and Society in the Drama of Early Modern England, New York, Palgrave, 2002, p. 25.

8. See Joan Hartwig, "Horses and Women in The Taming of the Shrew", Huntington Library Quarterly, 45.4 (1982), 285-294; F.E. Dolan, ed., William Shakespeare, The Taming of the Shrew. Texts and Contexts, New York, St. Martin's Press, 1996. For a comparison between early modern Hungarian 
and English cultural contexts, see Natália Pikli, "Across cultures: Shakespeare and the carnivalesque shrew”, European Journal of English Studies, 14.3 (2010), 235-248.

9. The Culture of the Horse. Status, Discipline, and Identity in the Modern World, eds Karen Raben and Treva J. Tucker, New York, Palgrave, 2005, p. 3. There are other volumes devoted to the cultural significance of horses, like Kevin de Ornellas's The Horse in Early Modern English Culture. Bridled, Curbed, and Tamed (Madison, Fairleigh Dickinson University Press, 2014). See also Charlotte Coffin, “'Hot horse to horse': le héros et sa monture dans le théâtre de Shakespeare", Etudes Epistémè, 20 (2011), https://journals.openedition.org/episteme/437\#tocto1n3. However, these works are not concerned with either centaurs or hobby-horses. Coffin mentions centaurs with relation to the Hamletian passage analysed later, but she arrives at different conclusions, focusing on the positive meanings of the centaur.

10. A listing of pertaining passages and works can be found in Anthony Dent, Horses in Shakespeare's England, London, J.A. Allen, 1987. However, he does not interpret these allusions in depth.

11. On Wither's preference of text over image, see his "To the Reader", George Wither, A Collection of Emblemes, Ancient and Moderne, London, printed by Augustine Matthews, 1635, sig. A2r. 12. Cf. the Burkean distinction between "little" and "great" tradition (Peter Burke, Popular Culture in Early Modern Europe, Farnham, Ashgate, 2009, p. 9 et passim). Although the validity of Burke's strict division between "great" and "little" traditions has been questioned in the face of the easy traffic between elite and popular phenomena in early modern England, his term concerning "amphibious" authors, like Shakespeare, remains a useful metaphor to describe people conversant in both traditions.

13. Francois Laroque, Shakespeare's Festive World. Elizabethan Seasonal Entertainment and the Professional Stage, transl. by J. Lloyd, Cambridge University Press, 1993, p.46. The evocative power of hobby-horses, together with that of old wives' tales and fairies is also emphasized by Mary Ellen Lamb, The Popular Culture of Shakespeare, Spenser and Jonson (Abingdon, Routledge, 2006).

14. Philip Stubbes, The Anatomy of Abuses, London, 1595, sig. M2r-v.

15. Object item 61, Fitzwilliam Museum, Cambridge, c. 1620 ( https:// webapps.fitzmuseum.cam.ac.uk/explorer/index.php?oid=1388). Vinckenboom's authorship is disputed, the 1960 catalogue lists it as by "an unknown artist, formerly (but no longer) attributed to D. Vinckenboons (sic)" (Gerson, Horst, Goodison, J.W., Catalogue of Paintings in the Fitzwilliam Museum, Cambridge, Vol. 1: Dutch and Flemish, Cambridge, Syndics of the Fiztwilliam Museum, 1960. p. 44.).

16. The Victoria and Albert Museum dates the Betley Window as 1550-1621, scholarly consensus has not been reached regarding the exact date.

17. Lowe first called attention to Meckenem's continental model (Barbara Lowe, "Early Records of the Morris in England", Journal of the English Folk Dance and Song Society, 8.2 (1957), 61-82).

18. The Oxford English Dictionary, s.v. "hobby-horse, 2."

19. Anon., Cobbes prophecies and tokens, London, 1614.

20. Shannon elaborates on the significance of Pliny's Historia naturalis on early modern English natural history, op. cit., p. 178.

21. Dierck Pietersz' Bellerophon, of Lust Tot Wyshed [Bellerophon or Thirst for Wisdom, including virtue and order. Instructive emblems and their explanations] Amsterdam, 1614. Original copy consulted in Cambridge University Library.

22. The following data are based on Hans Biedermann's Lexikon der Symbole (Munich, Droemer Knaur, 1989), s.v. 'Kentaur'.

23. A relevant Hungarian example can be found in a late $15^{\text {th }}$-century illuminated codex, the breviary of Domonkos Kálmáncsehi, Hungarian Humanist scholar and high priest. Two centaurs (and a naked couple) appear in a beautiful illumination of the Christmas vigil by Francesco Castello d'Ithallico. Edina Zsupán argues that the naked couple confirms the influence of Ficino's 
Neoplatonic philosophy, opposed to the centaurs' hybridity and "natural wildness", that is the centaurs allegorically stand for beastly passion in man. Edina Zsupán, "Philosophia picta. A firenzei újplatonizmus budai recepciójához" [Philosophia picta. The Reception of Florentine NeoPlatonism in Buda], Az identitás forrásai, Hangok, szövegek, gyüjtemények [Sources of Identity. Voices, Texts, Collections], eds L. Boka, F. Földesi, B. Mikusi, Budapest, Gondolat, 2012, p.97-116.

24. This epithet occurs quite frequently not only in Ovid, cf. the listing in Márta Hargitai, "Kentaurok Shakespeare Lear királyában, a képzőművészetekben és a mitológiában" [Centaurs in Shakespeare's King Lear, in arts and mythology], Desiré: Gondolat és Müvészet Irodalmi Szemle, 4 (2002), 2-6, and see Jonathan Bate, Shakespeare and Ovid, Oxford, Oxford University Pres, 1993.

25. Qtd in Eric C. Brown, “'Many a civic monster': Shakespeare's Idea of the Centaur", Shakespeare Survey, 51 (1998), 175-191, p.177-178.

26. Oxford English Dictionary, 'centaur, n.'1a.

27. Andreas Höfele, Stage, Stake and Scaffold. Humans and Animals in Shakespeare's Theatre, Oxford, Oxford University Press, 2011, p. 26.

28. Edward Topsell, The historie of foure-footed beastes, London, William Jaggard, 1607, p. 319, lines 18-26.

29. Qtd in Oxford English Dictionary, 'centaur, n.', $1 \mathrm{~b}$.

30. Brown pointed out how variously Sidney's Arcadia (1586) is used in Hamlet (Brown, op. cit., p. 175.), however, he seems untroubled with the problem of the physical positioning of the rider/ horse.

31. Thomas Nashe, A Pleasant Comedie, called Summers last will and Testament (perf. 1592), London, printed by Simon Stafford for Walter Burre, 1600, sig. B3v-B4r.

32. The other minor variation concerns the name mentioned: Lamord (Q2) and Lamound (F).

33. William Shakespeare, Hamlet, The Arden Shakespeare Second Series, editor Harold Jenkins, Walton-on-Thames, Thomas Nelson, 1997, 4.7.80-86. (emphasis mine)

34. William Shakespeare, Hamlet. Revised Edition. The Arden Shakespeare Third Series, eds Ann Thompson and Neil Taylor, London, Bloomsbury, 2016, p. 430.

35. Jenkins, op.cit., p. 543-544.

36. Moseley emphasizes that besides constant innovation, "a core of emblem pictures" existed, "of which most people would have been aware". Charles Moseley, A Century of Emblems: an introductory anthology, Aldershot, Scolar Press, 1989, p. 12.

37. The discussion and comparison of the following continental emblems is based on the web databases of Alciato at Glasgow, The Alciato Project and Emblematica Online, where all versions are available. For Plato, see the Internet Classics Archive, 'Stateman (Politicus)', http:// classics.mit.edu/Plato/stateman.html, last accessed 1 December 2019.

38. Geoffrey Whitney, A choice of emblemes, and other deuises, for the moste part gathered out of sundrie writers, Leyden, in the house of Christopher Plantyn, by Francis Raphalenguis, 1586, p. 38. An emblem book of lesser significance, George Willet's Sacrorum emblematum centuria vna (Cambridge, Iohannis Legate, 1592) also features 'naked' emblems but 'Emblema 33' describes a woman holding a bridle, and a rider controlling a horse with the lesson that men should control their rage, and tongue.

39. John Manning, "Introduction", Geoffrey Whitney, A Choice of Emblemes, Aldershot, Scolar Press, 1989, 1-13. The emblem book facsimile contains this emblem under the motto 'Non locus virum, sed vir locum ornat', p. 38.

40. Henry Peacham, Minerua Britanna or A garden of heroical deuises, London, W. Dwight, 1612, p. 93.

41. Potter, ed. The Two Noble Kinsmen, op. cit., p.45.

42. Brown also calls attention to the similarity of these passages in brief, without reference to the hobby-horse. Brown, op. cit., p. 181-182.

43. Benjamin Arbel, "The beginnings of comparative anatomy and Renaissance reflections on the human-animal divide”, Renaissance Studies, 31.2 (2017), 201-222, p.204-205. 
44. Douglas J. Stewart, "Falstaff the Centaur", Shakespeare Quarterly, 28.1 (Winter 1977), 5-21, p. 6-7.

45. See Stewart, op. cit.

46. This is how centaurs are recalled in Titus Andronicus with Titus slitting the throats of the rapers and murderers (one of whom is ironically named Chiron) with the words: "To make this banquet [...] / More stern and bloody than the Centaurs' feast" (5.2.201-202). See also Brown, as centaur 'in bono', 'in malo', op. cit., p. 177, 183.

47. Donald Lupton, Emblems of rarities: or Choyce observations out of worthy histories of many remarkable passage, London, printed by N. Okes, 1636, p. 407.

48. Qtd in Oxford English Dictionary, 'centaur, n.', 3 b.

49. The widespread popularity of Ovid's Metamorphoses is well-known, however, it might be interesting to point out that Golding's 1567 translation mentions the 'beastliness' of centaurs already in the prefatory "The Epistle" (1. 246-248, p. 6): "The frentick fray betweene the Lapithes and / The Centaures is a note wherby is given to understand /The beastly rage of drunkennesse" (The XV. Nookes of P. Ouidius Naso, entytuled Metamorphosis, translated oute Latin into English meter, by Arthur Golding Gentleman..., London, Willyam Seres, 1567; Facsimile edition by W.H.D. Rouse, London, De La more Press, 1904.)

50. Shannon, op. cit., p. 174.

51. Topsell, op. cit., p. 337, for all quotations in this paragraph.

52. I owe my thanks for the Latin transcription and explanation to Máté Ittzés, a scholar of classical philology at Eötvös Loránd University. He also called my attention to the fact that interestingly, the Horatian ode (mis)quoted by Topsell, tilts towards a gendered monstrosity, since the Roman poet writes about the ugliness of an imaginary female hybrid, with a human head, a horse's neck, feathers and a fish's tail in Ars Poetica (https://www.thelatinlibrary.com/ horace/arspoet.shtml, last accessed 15 September 2019)

53. Boehrer, op. cit., p. 28-40, 17-27.

54. Brown refers to the hobby-horses' "same lasciviousness as centaurs", but only referring to Othello and Love's Labour's Lost, where the word clearly means 'whore'. Brown, op. cit., p. 189. His interpretation echoes the most frequent scholarly view: "Here, the King evokes the lustful nature of the centaur, and projects that nature onto the lower half of women" (Brown, op. cit., p. 183-184.). Brown mentions the beautiful and true Ovidian female centaur, Hylonome, but the idea of female centaurs was rather unknown in the age. Stewart confirms that sources are vague about female centaurs, whereas male centaurs raping women are stock iconographical images on vases (Stewart, op. cit., fn 5). Cf. also Page DuBois, Centaurs and Amazons. Women and the Pre-History of the Great Chain of Being, Ann Arbor, The University of Michigan Press, 1991. p.31.

55. Claudette Hoover, "Women, centaurs, and devils in King Lear", Women's Studies, 16 (1989), 349-359.

56. Höfele, op. cit., p.191-193.

57. William Shakespeare, Twelfth Night, or What You Will, 2.2.33-39. Folger Digital Texts. FTLN 0693-699.

58. Relevant studies and contemporary primary sources are too numerous to quote here, for introduction, see Dolan.

59. The anonymous quarto from 1609 , old Meg of Herefordshire, which describes a parodically exaggerated morris dance, also reaffirms this: "But looke you who here comes: John Hunt the Hobby-horse, wanting but three of a hundred, twere time for him to forget himselfe, and sing, but $\mathrm{O}$, nothing but $\mathrm{O}$, the Hobbie-horse is forgotten", old Meg of Herefordshire for a Mayd Marian and Hereford Towne for a Morris Dance, London, printed for John Budge, 1609, sig. B4r. 


\section{ABSTRACTS}

Shakespearean centaurs and centaur-like images have received scholarly attention with relation to Ovid as well as to early modern philosophy, regarding the human-animal divide. This paper argues for a nuanced re-reading of relevant textual cruces in Hamlet, King Lear and The Two Noble Kinsmen in the light of a specific fusion of popular and elite cultures in the man-horse hybrid, as represented by the (male/female) centaur and the early modern hobby-horse, emphasizing the stigmatisation (the "monstrosity") of bestial passion and illicit sexuality, signified by the hybrid creature and its animal part. English emblem books and Edward Topsell's 1607 volume on "fourfooted beasts" present a complex background to the re-visitation of these well-known passages, and illuminate how Shakespeare used elements of both popular and elite cultures to suit his dramaturgical ends and to address different strata of the audience. The paper offers an overview of the complex iconographical and conceptual semantics of centaur-like creatures, as they existed in Shakespeare's contemporaries' imagination, suggesting a tentative summary of the cultural memory of the centaur in early modern England.

La représentation de centaures et de figures assimilées dans l'œuvre de Shakespeare est souvent étudiée en lien avec Ovide et la philosophie de la Renaissance, dans une analyse de la différence entre l'humain et l'animal. Cet article propose une relecture nuancée des passages pertinents dans Hamlet, Le Roi Lear et Les Deux Nobles Cousins à la lumière d'une figure hybride, produit d'une fusion des cultures élitistes et populaires : l'homme-cheval, représenté par le centaure (mâle ou femelle) et l'homme à tête de cheval, frappé par la stigmatisation (la "monstruosité ») de la passion bestiale et de la sexualité illicite incarnée par son hybridité et son animalité. Les livres d'emblèmes anglais et l'ouvrage d'Edward Topsell consacré aux «bêtes à quatre pieds » (1607) permettent de remettre en contexte ces passages bien connus, afin d'analyser l'utilisation par Shakespeare d'éléments tirés des cultures élitistes et populaires, adaptés par le dramaturge à ses objectifs et aux différents types de publics visés. Cet article étudie la sémantique conceptuelle et iconographique complexe des créatures assimilées au centaure, telles qu'elles existaient dans l'imagination des contemporains de Shakespeare, proposant ainsi un panorama de la mémoire culturelle du centaure dans l'Angleterre de la première modernité.

\section{INDEX}

Mots-clés: culture populaire, discours genrés, histoire naturelle, livres d'emblèmes, Peacham Henry, Shakespeare William, Topsell Edward, Wither George

Keywords: early modern natural history, emblem books, gendered discourses, Peacham Henry, popular culture, Shakespeare William, Topsell Edward, Wither George

\section{AUTHOR}

\section{NATÁLIA PIKLI}

Eötvös Loránd University (Budapest, Hungary) 